\title{
STRATEGI PENGEMBANGAN INDUSTRI KRIYA LOGAM DI DESA TUMANG CEPOGO BOYOLALI
}

\author{
Aan Sudarwanto ${ }^{1}$ (Jurusan Kriya Fakultas Seni Rupa dan Desain Institut Seni Indonesia Surakarta) \\ Kuntadi Wasi Darmojo² (Jurusan Kriya Fakultas Seni Rupa dan Desain Institut Seni Indonesia Surakarta)
}

\begin{abstract}
This article is the result of community service, taking the theme of the Development of Metal Craft Industry. The aim is to increase the competitiveness of the metal craft industry in the village of Tumang Cepogo Boyolali. With a focus on handling product quality and production speed so that they can compete as export products. The method or approach used in the development of the metal craft industry includes training education with lecture, interactive, guidance and mentoring techniques. Then the design and application supervision was carried out as well as the provision of appropriate technology equipment stimulation to solve production problems. The main problem of SMEs especially metal craft in Tumang village is the use of simple tools, which is one of the reasons why handicraft products cannot meet market demand in a short time. So we need a strategy on how to solve these problems. Besides that, there are many other problems that need handling as a form of development strategy. Among them are handling raw material problems, design, production tools, promotion strategies, marketing and management of human resources. The focus of this empowerment activity is more directed at aspects of improving the quality of metal handicraft production which includes strengthening production systems, strengthening human resources, utilizing appropriate technology use, design, design and product branding which ultimately lead to the export of metal craft products.
\end{abstract}

Keywords: Empowerment, metal crafts, quality

\section{ABSTRAK}

Artikel yang merupakan hasil pengabdian pada masyarakat ini, mengambil tema Pengembangan Industri Kriya Logam. Adapun tujuannya untuk meningkatkan daya saing industri kriya logam yang berada di desa Tumang Cepogo Boyolali. Dengan menitikberatkan pada penanganan kualitas produk dan kecepatan produksi sehingga mampu bersaing sebagai produk ekspor. Metode atau pendekatan yang digunakan di dalam pengembangan industri kriya logam ini antara lain menggunakan pendidikan pelatihan dengan teknik ceramah, interaktif, bimbingan dan pendampingan. Kemudian dilakukan supervisi desain dan aplikasinya serta pemberian stimulasi peralatan teknologi tepat guna untuk memecahkan persoalan produksi. Problem utama UKM khususnya kriya logam di desa Tumang adalah penggunaan alat yang sederhana, merupakan salah satu sebab mengapa produk kriya tidak bisa memenuhi permintaan pasar dalam waktu yang singkat. Sehingga diperlukan strategi bagaimana memecahkan permasalahan tersebut. Disamping itu banyak permasalahan-permasalahan lain yang diperlukan penanganan sebagai bentuk strategi pengembangan. Diantaranya penanganan permasalahan bahan baku, desain, alat produksi, strategi promosi, pemasaran dan pengelolaan sumber daya manusia.Fokus dari kegiatan pemberdayaan ini lebih diarahkan pada pada aspek peningkatan kualitas produksi Kerajinan logam yang meliputi penguatan sistem produksi, penguatan sumber daya manusia, pemanfaatan teknologi tepat guna, perancangan desain, dan branding produk yang akhirnya bermuara pada eksport hasil produk kerajinan logam.

Kata kunci : Pemberdayaan, kriya logam, kualitas 


\section{PENDAHULUAN}

Kriya merupakan kegiatan seni yang menitik beratkan kepada keterampilan yang mengolah berbagai macam bahan baku yang sering ditemukan di lingkungan sekitar kita, mengubah menjadi benda-benda yang tidak hanya bernilai pakai, tetapi juga bernilai estetis. Sebuah karya kriya umumnya dibuat dengan menggunakan keterampilan tangan (hand skill) dan memperhatikan segi fungsional (kebutuhan fisik) dan keindahan (kebutuhan emosional) (Soegeng Toekio, at all, 1987, p. 12)

Karya kriya atau bisa juga disebut dengan produk kriya, dikategorikan sebagai karya seni rupa terapan. Dalam perkembangannya, karya kriya identik dengan seni kerajinan. Salah satu kerajinan yang paling menonjol adalah kerajinan logam dimana konsentrasi penggunaan bahan baku utama didominasi bahan baku logam seperti tembaga, aluminium dan kuningan. Hal ini seperti yang terdapat di di Desa Tumang Cepogo Boyolali.

Kerajinan logam di Desa Tumang merupakan warisan budaya turun-temurun. Sebagian besar warga Tumang memiliki keterampilan membuat kerajinan tembaga, aluminium dan kuningan secara turun menurun. Pada mulanya desa ini banyak memproduksi peralatan rumah tangga seperti dandang, wajan, kwali, kendil, dan lain-lain. Seiring kemajuan jaman, kerjinan tembaga dan kuningan di Desa Tumang mengalami perkembangan, dengan sentuhan kreativitas. Akhirnya produk-produk yang diproduksi kini dapat menjadi barang-barang seni kerajinan yang bermutu tinggi. Produk kriya logam tembaga, aluminium dan kuningan di Desa Tumang hingga kini terus mengalami perkembangan, tak hanya memproduksi benda-benda kerajinan dalam ukuran kecil, tetapi dibeberapa home industri di Tumang juga mengerjakan berbagai pesanan hiasan dalam ukuran besar, misalnya hiasan gapura, hiasan relief, kubah tempat ibadah, dan lain sebagainya.

Berpijak dari kondisi sentra kerajinan logam di desa Tumang tersebut dan dikaitkan dengan program pemberdayaan masyarakat, maka dipilih mitra kegiatan untuk perusahaan kriya logam, yakni dua pengusaha bernama Sudarto-Sukarni dan Slamet Amik yang dianggap mewakili profil sentra kerajinan logam desa Tumang. Saat ini Sudarto bersama istrinya Sukarni sedang merintis kerajinan logam tembaga dan kuningan bernama "CV. Kusuma Logam" dan berkeinginan untuk mengembangkan usaha produksinya sampai dapat menembus pasar luar negri. Sedangkan Slamet Amik adalah pemuda yang berkeinginan mengembangkan perusahaan kerajinan logamnya dengan bendera "CV. Amik Art Gallery" yang berdomisili di desa Tumang kecamatan Cepogo kabupaten Boyolali. Desa Tumang merupakan desa yang terletak di dataran tinggi yang menjadi primadona kabupaten Boyolali, karena merupakan jalur objek wisata, hawanya dingin, dan pemandangan alam yang elok.

Fokus dari pemberdayaan ini lebih diarahkan pada pada aspek peningkatan kualitas produksi Kerajinan logam yang meliputi penguatan sistem produksi, penguatan sumber daya manusia, pemmanfaatan teknologi tepat guna, perancangan desain, dan branding produk yang akhirnya bermuara pada eksport hasil produk kerajinan logam.

Sumber daya manusia yang dimiliki oleh dua pengusaha Sudarto-Sukarni dan Slamet Amik kebanyakan tenaga kerja yang direkrut adalah para pemuda dan kerabat di lingkungan sekitar lokasi yang kesemuanya masih memerlukan pembinaan dalam hal ketrampilan, sehingga masih perlu diberikan satu pelatihan yang lebih intensif. Dalam hal ketrampilan dasar keteknikan kriya logam. Kedua pengusaha tersebut dapat dikatakan sudah memilikinya, namun dalam hal aplikasi teknologi dan efisiensi masih membutuhkan pelatihan dan pendampingan. Demikian halnya dengan upaya untuk menciptakan desain dan pembuatan merk dagang, keduanya dapat dikatakan belum mampu sehingga masih sangat membutuhkan hasil kajian ilmiah dari akademisi perguruan tinggi. Atas dasar realitas tentang potensi dan peluang usaha, aspek produksi dan manajemen usaha, serta eksistensi sumber daya yang dimiliki kedua pengusaha maka nampak jelas begitu perlunya dilakukan 
kegiatan pengabdian kepada masyarakat yang difokuskan pada pemberdayaan kerajinan logam bagi kedua perusahaan kerajinan logam tersebut.

\section{METODE PELAKSANAAN}

Metode pelaksanaan kegiatan yang dipilih akan sangat menentukan tingkat keberhasilan suatu kegiatan. Adapun beberapa metode yang digunakan pada kegiatan ini adalah meliputi hal-hal sebagai berikut:

1. Metode ceramah plus.

Merupakan metode yang bertujuan memberikan pengetahuan dan petunjukpetunjuk dimana terdapat audien yang bertindah sebagai pendengar. Ceramah, dapat dilakukan dengan cara kreatif dan inovatif (Soedarsono RM, 2001, 57). Metode ceramah plus adalah metode mengajar yang menggunakan lebih dari satu metode, yakni metode ceramah yang digabung dengan metode lainnya. Pada kegiatan ini perpaduan metode yang digunakan adalah metode ceramah plus demonstrasi dan latihan

2. Metode bimbingan dan pendampingan. Pendampingan dilakukan oleh fasilitator atau pendamping kegiatan. Fasilitator tugasnya lebih sebagai pendorong, penggerak, katalisator, motivator, pengarah dan pembimbing (Ambar Teguh Sulistiyani, , 2004, 76).

Pasca kegiatan pelatihan kegiatan selanjutnya adalah praktek produksi produk kerajinan. Pendampingan menjadi sangat penting untuk membimbing dan menjaga kualitas produk yang dihasilkan.

3. Desain dan Aplikasinya.

Metode ini untuk memberi beberapa alternatif desain baru bagi UKM mitra yang berbasis pada program rancang bangun komputer desain.

4. Pengadaan peralatan dan perlengkapan.

Sebuah produksi agar tercapai efektifitas dan efisiensi produksi, perlunya didukung peralatan dan perlengkapan produksi. Peralatan dan perlengkapan ini dapat yang bersifat tepat guna maupun yang bersifat pabrikasi.

\section{PEMBAHASAN}

Strategi pengembangan industri kriya logam di desa Tumang dilakukan dengan mengambil mitra yang mempresentasikan UKM sebagai bentuk konsentrasi pengembangan. Kemudian dilakukan pemataan permasalahan yang ada, baru dilakukan langkah-langkah tindakan. Beberapa tindakan yang dilakukan bersifat mendasar atau basic, merupakan fondasi sebagai langkah pengembangan pada tahap berikutnya. Beberapa aspek yang ditangani antara lain bahan baku, desain produk, alat produksi, manajemen dan pengembangan sumber daya manusia. Penanganan aspekaspek tertebut sebagai bentuk strategi pengembangan industri kriya logam adalah sebagai berikut.

\section{Bahan Baku}

Bahan baku produk yang dipergunakan di mitra kerajinan logam Tumang adalah salah satunya logam alluminium. Dari bahan baku tersebut dicoba untuk dikembangkan agar mempunyai nilai tambah. Pengembangkan bahan baku alluminium dilakukan dengan eksperimentasi finishing yang tujuan untuk meningkatkan nilai jual. Adapun hasil pengembangan eksperimen finishing tersebut adalah menggunakan Teknik Powder Coating.

Powder coating merupakan teknik finishing dengan proses pelapisan pada permukaan objek yakni benda kerajinan yang terbuat dari aluminium dengan suatu lapisan film. Secara ringkas dapat dijelaskan sebagai berikut.

Powder coating dalam bentuk film bubuk digunakan dalam lapisan tipis workpiece kemudian dilarutkan dalam bentuk film dan dipanaskan untuk polimerisasi dan mengawetkan coating. Powder dilekatkan pada permukaan profil aluminium/Besi dengan menggunakan alat electric spray gun. Partikel yang bermuatan negatif diletakkan ke benda kerja. Besarnya muatan partikel tersebut tergantung dari besarnya medan listrik (E) ketika muatan negatif gaya yang timbul tergantung arus yang mengalir dan lamanya waktu yang 
digunakan. Pada saat powder coating disemprotkan arahnya tidak lurus ke benda kerja tetapi membentuk suatu wrap round effect. Hal ini akan memberi keuntungan karena powder coating dapat menjangkau bagian yang terlindungi.

Dari ekperimen ini diharapkan terjadi peningkatan nilai jual produk dan sekaligus dapat menjadi tambahan variasi produk UKM mitra di desa Tumang Cepogo Boyolali.

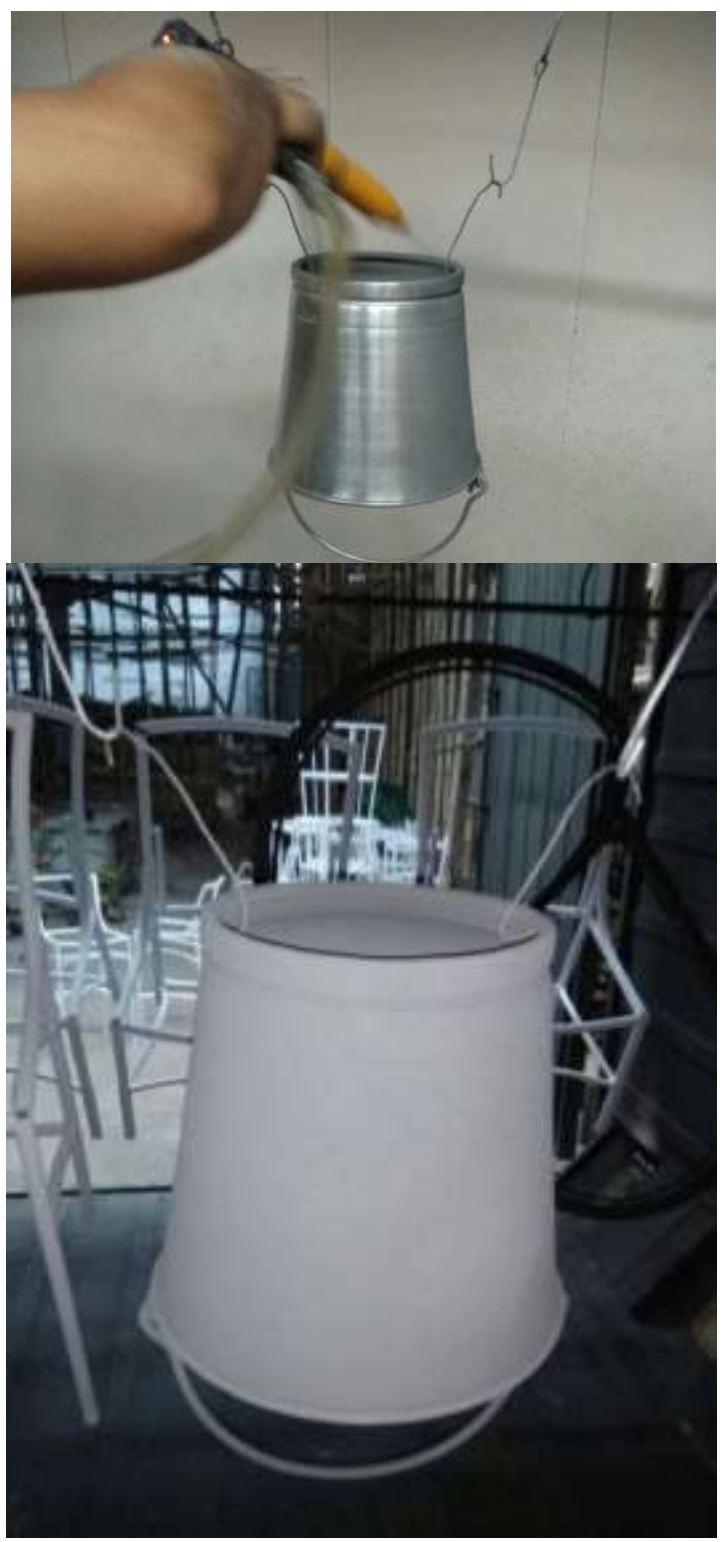

Gambar 1. Proses pewarnaan dengan powder Coating, menggunkan elektrik spray gun yang disemprotkan dengan arah memutar (Foto : Sudarto, 2017)

\section{Desain Produk}

Setrategi pengembangan desain produk terbagi menjadi 3 karakter yang bertujuan untuk menghasilkan produk yang lebih menarik agar tidak bergantung pada produk pesanan sehingga diharapkan stabilitas produksi dan ketahanan usaha dapat lebih baik. Ketiga karakter sebagai bentuk strategi pengembangan desain tersebut antara lain.

a. Pengembangan desain produk beridentitas

b. Pengembangan desain fungsi yang lebih ergonomis

c. Desain berkarakter dengan ciri khusus

Produk beridentitas berfungsi sebagai penanda bahwa unit usaha UKM menghasilkan produk dengan ciri kusus yang dapat diketahui konsumen. Disamping itu berfungsi untuk membedakan dengan penjual atau usaha UKM lain yang sejenis sehingga memiliki nilai yang berbeda. Identitas produk dapat berbentuk logo, nama, trademark atau gabungan dari keseluruhannya. Perusahaan yang peka dengan suatu identitas produk akan menyadari bahwa nama brand adalah identitas diri dari sebuah perusahaan dan menjadi nilai tambah dalam penjualan produk mereka. Hal ini sesuai dengan pendapat Kloter bahwa Brand berfungsi mengidentifikasi barang atau jasa dari seseorang atau sekelompok penyaji dan membedakan dari produk sejenis dari penyaji lain (Kotler, Philip. 2002,163). Merupakan value yang ditawarkan kepada konsumen, terlebih jika dipandang dari sudut pandang konsumen, maka nama brand adalah total akumulasi dari semua pengalaman yang dialami dan dibangun berdasarkan kontak dengan konsumen.

Mengingat pentingnya hal tersebut maka dalam strategi pengembangan desain produk pada kegiatan pengabdian ini, aspek produk beridentitas menjadi skala prioritas. Langkah awal yang telah dilakukan antara lain :

a. Membuat desain logo perusahaan

b. Membuat desain label produk

c. Pengaplikasian logo pada sarana dan media promosi, terdiri dari Papan nama perusahaan, Katalog produk, 
Kop surat, Kartu Nama, Web, Media on line

d. Pengaplikasian logo pada produk yang dihasilkan, dengan menggunakan teknik press dan teknik tempel yang desesuaikan dengan karakter produk yang dihasilkan.

Beberapa desain pengembangan juga dilakukan dengan memberikan motif sebagai ciri khas produk mitra yakni motif kusuma logam. Selain itu beberapa produk fungsional mitra seperti milkcan juga dibuat desain pengembangannya dengan menggunakan kaidah ergonomic sebagai alternative varian produk. Hasil pengembangan desain produk yang dilakukan pada UKM mitra dapat dilihat pada gambar berikut ini.

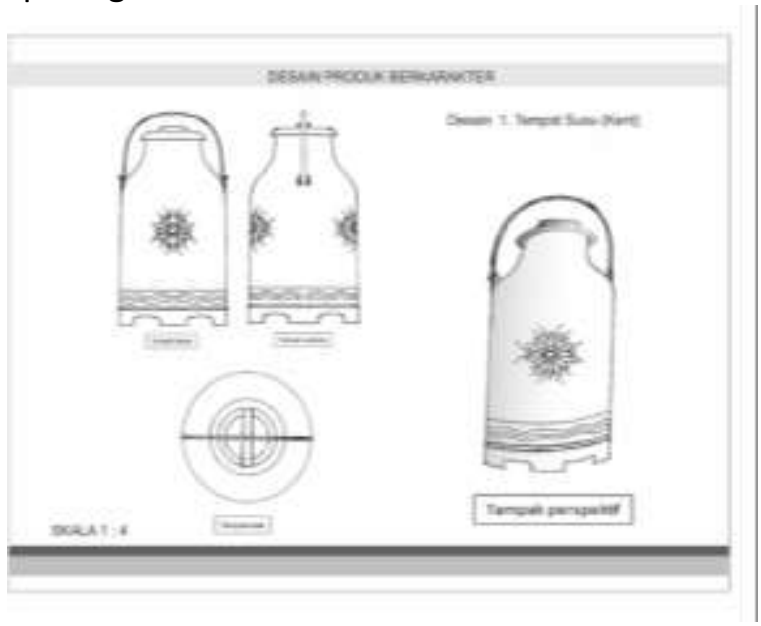

Gambar 2. Desain pengembangan produk milk can dengan tambahansentuhan motif bunga

kusuma yang telah di stilir menjadikan tampak lebih berkarakter.

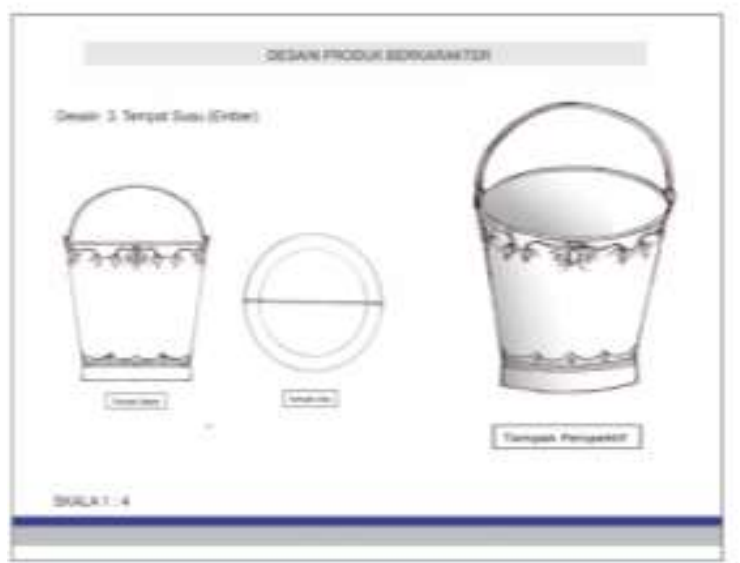

Gambar 3. Desain pengembangan produk ember pemerah susu dengantambahan sentuhan motif bunga kusuma yang telah di stilir menjadikan tampak lebih berkarakter

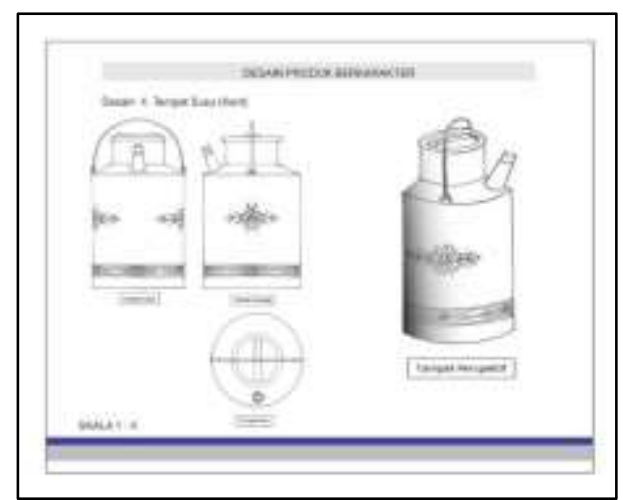

Gambar 4. Desain pengembangan produk milk can dengan tambahan kucu (tempat penuangan) sehingga lebih ergonomis dan tambahan sentuhan motif bunga kusuma yang telah di stilir menjadikan tampak lebih berkarakter

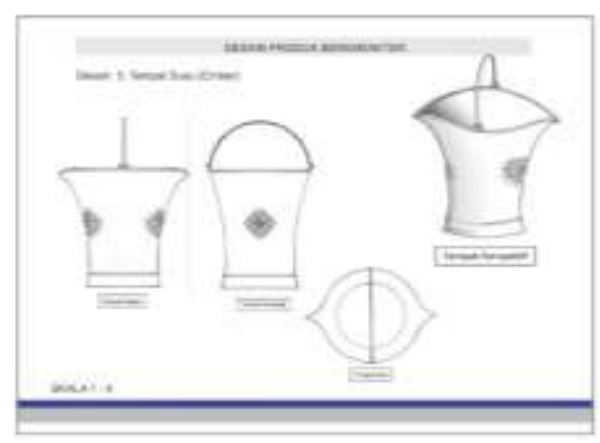

Gambar 5 Desain pengembangan produk ember pemerah susu dengan tambahan corong (tempat penuangan) sehingga lebih ergonomis dan tambahan sentuhan motif bunga kusuma yang telah di stilir menjadikan tampak lebih berkarakter

\section{Pengembangan Alat Produksi}

Untuk meningkatkan proses produksi agar hasil produksi dapat lebih presisi dan waktu pengerjaan dapat lebih dipersingkat maka dilakukan perancangan alat teknologi tepat guna (TTG) yang berfungsi sebagai pembentukan spin dasar. Alat tersebut sangat membantu dalam membuat komponen-komponen produk kerajinan logam dalam mendukung proses pembentukan. Adapun rancangan alat tepat guna tersebut dapat dilihat pada gambar berikut. 


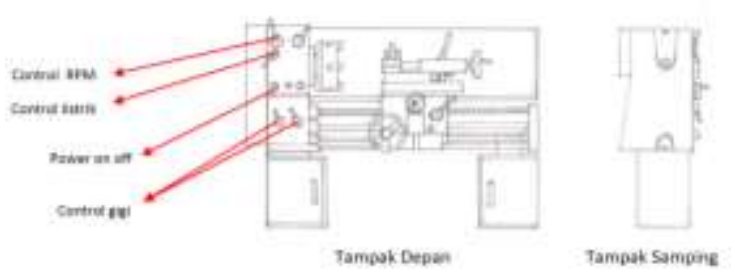

Gambar 6. Desain alat Teknologi Tepat Guna (TTG) sebelumdirekayasa merupakan mesin bubut bekas (untuk membuat bubutan)

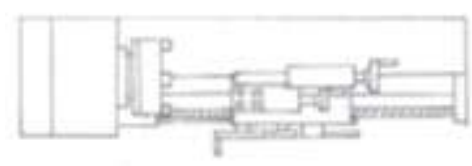

Skala : $1: 100$

\section{Tampak Atas}

Gambar 7. Desain alat Teknologi Tepat Guna (TTG) setelah direkayasamenjadi Mesin Spining (untuk membuat bentuk dengan menekan)

Perlu diketahui bahwa esensi dari rekayasa mesin teknologi tepat guna ( TTG ) ini adalah merupakan salah satu solusi dari permasalah yang ada di mitra kerajinan logam Tumang terutama mengenai proses produksi (teknik pembentukan), berangkat dari temuan dilapangan tersebut kemudian dilakukan perancangan terkait dengan salah satu peralatan yang menunjang proses produk di mitra kerajinan logam Tumang yakni melakukan rekayasa membuat alat Teknologi Tepat Guna (TTG). Tujuannya untuk meningkatkan produktivitas produksi yang semula apabila sehari seorang perajin hanya menghasilkan satu buah produk secara manual, kemudian setelah mempergunakan mesin hasil rekayasa tersebut sehari bisa menghasilkan minimal 20 buah produk, dengan demikian munculnya mesin rekayasa tersebut mendorong produktivitas bagi perajin di mitra kerajinan logam Tumang. Adapun alat Teknologi Tepat Guna (TTG) ini merupakan hasil rekayasa dari mesin bubut bekas, yang dirubah menjadi mesin spaning, dimana yang awalnya berfungsi sebagai mesin bubut beralih fungsi menjadi mesin untuk membuat bentuk cembung-cekung dengan teknik menekan putar. Metode perancangan dilakukan dengan cara memodifikasi dari berbagai elemen yang ada terutama pada bagian sumbu as putaran dan landasan pisau serta sekaligus roda penekannya. Dari elemen-elemen tersebut direkayasa dengan diganti terutama pada bagian landasan pisau dan pada sumbu as sebagai tempat benda yang akan menjadi landasan tempat benda yang dibuat. Kemudian dari landasan pisau diganti dengan bentuk yang sederhana berupa plat baja setebal $1 \mathrm{~cm}$ dengan dilengkapi baut sebagai controling pisau penekan, selanjutnya pada kedua bagian sumbu as diberi matras dari baja/kayu sebagai model untuk membuat bentuk, (bentuk matras bervariasi sesuai bentuk produk yang diinginkan), maka dengan demikian alat tersebut yang semula merupakan alat mesin bubut berubah menjadi alat mesin spining.

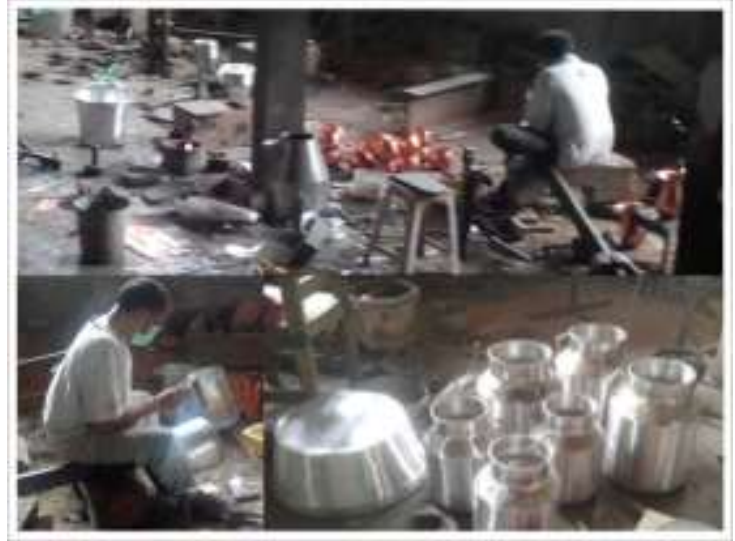

Gambar 8. Pembentukan manual dengan teknik kenteng yakni plat logam dibentuk dengan cara dipukul terus menerusmembentuk sebuah objek yang diinginkan.

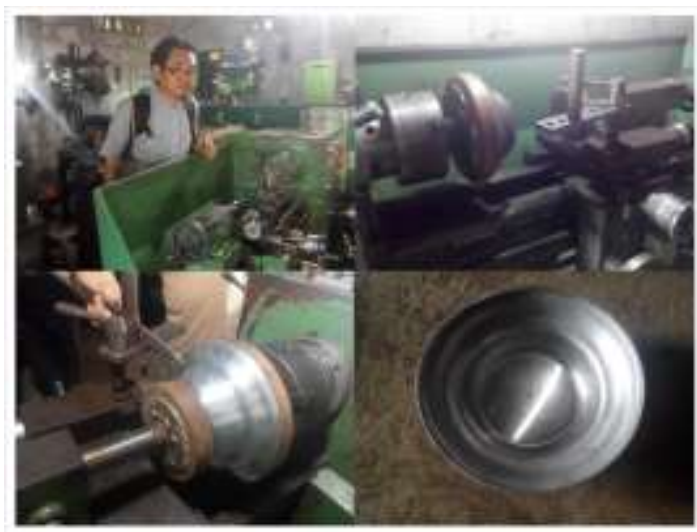

Gambar 9. Alat hasil rekayasa teknologi tepat guna, merubah mesin bubut menjadi alat pembentuk plat logam dengan tekniik tekan putar. Merupakan langkah merubah kecepatan produksi menjadi lebih baik sehingga menjadi salah satu solusi 
memecahkan permasalahan kelambanan produksi.

\section{Pengembangan Manajemen dan Pemasaran}

Hasil dari penanganan manajemen dan pesaran pada kegiatan ini diawali dengan dilakukannya kegiatan pendidikan dan pelatihan yang menjadi dasar penerapan system manajemen dan pemasaran. Pendidikan dan pelatihan ditekankan pada dua aspek antara lain, aspek pengelolan karyawan dengan system reward dan panisment. Sedangkan aspek pengelolan pemasaran dengan system on line melalui pembuatan web site. Penghargaan (reward) merupakan sebuah bentuk apresiasi kepada suatu prestasi tertentu yang diberikan, baik oleh dan dari perorangan ataupun suatu lembaga yang biasanya diberikan dalam bentuk material atau ucapan. Dalam organisasi ada istilah insentif, yang merupakan suatu penghargaan dalam bentuk material atau non material yang diberikan oleh pihak pimpinan organisasi perusahaan kepada karyawan agar mereka bekerja dengan menjadikan modal motivasi yang tinggi dan berprestasi dalam mencapai tujuan-tujuan perusahaan.

Sedangkan punishment merupakan sebuah cara untuk mengarahkan sebuah tingkah laku agar sesuai dengan tingkah laku yang berlaku secara umum. Dalam hal ini, hukuman diberikan ketika sebuah tingkah laku yang tidak diharapkan ditampilkan oleh orang yang bersangkutan atau orang yang bersangkutan tidak memberikan respon atau tidak menampilkan sebuah tingkah laku yang diharapkan. Pada UKM kerajinan logam kami cobakan dengan cara system buka tutup dimana kinerja karyawan diukur dengan hasil yang dihasilkan. Sedangkan jika terjadi kesalahan produksi maka akan diukur tingkat kesalahannya kemudian diberikan punishment perupa pengurangan pembayaran. Secara rinci model reward dan punishment dapat dilihat dalam tabel berikut.

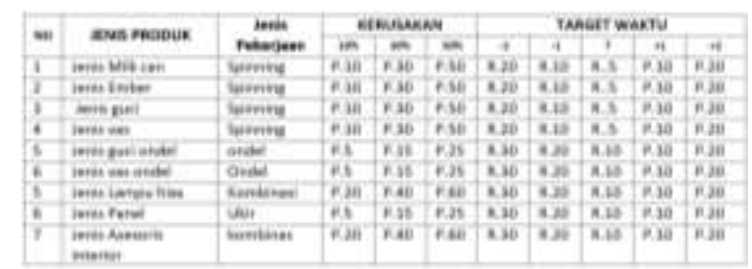

Tabel Model reward dan punishment dengan menetapkan angka sangsi sesuai dengan tingkat kesalahan dan angka reward sesuai dengan tingkat ketepatan waktu pengerjaan

\section{Pengembangan SDM}

Berangkat dari temuan di lapangan bahwa salah satu kendala untuk eksistensi kerajinan logam di Tumang adalah mulai berkurangnya tenaga perajin terutama mengenai tenaga membuat bentuk dengan teknik ondel (kenteng) dan kurangnya pemahaman terhadap pembuat desain sebuah produk. Berangkat dari kasus tersebut maka dalam program pengabdian ini merasa perlu adanya program pendidikan dan pelatihan desain terkait dengan produk kerajinan logam di Tumang. Pendidikan dan pelatihan mengenai desain tersebut melibatkan para perajin yang bekerja di kedua mitra kerajinan logam tersebut yang ditambah beberapa perajin logam yang lain namun masih dalam satu wilayah perajin logam di Tumang. Jumlah para peserta ada sekitar 15 perajin yang rata masih berumur antara 17 30 tahun, kenapa demikian karena dari umur tersebut diharapkan para perajin bersedia untuk melakukan praktik membuat desain sampai pada prototipe.

Materi pendidikan dan pelatihan di mitra kerajinan logam Tumang tersebut meliputi antara lain : estetika, ukuran yang ideal, memahami kehendak konsumen, karakter konsumen, penguasaan pengalaman tentang produk dan pengenalan ornamen, selain itu juga diberikan meteri terkait bagaimana cara membuat desain secara baik dan benar serta mengenai bagaimana membuat packejing. Adapun tujuan dari pendidikan dan pelatihan tersebut adalah untuk menumbuhkan dan meningkatkan kesadaran para perajin logam di Tumang terutama para tenaga perajin di kedua mitra kerajinan logam Tumang yakni CV kusuma Logam dan Amik Galleri, sehingga setelah mengikuti pendidikan dan pelatihan desain 
tersebut para perajin logam di Tumang bisa dan memiliki motivasi untuk melakukan kreativitas di bidang produk melalui desain.

\section{KESIMPULAN}

Pengembangan industri kriya logam di desa Tumang Cepogo Boyolali ini, menjadi sebuah kegiatan penting ketika berangkat dari permasalahan mendasar yang dialami oleh para pengrajin. Kegiatan pengabdian kepada masyarakat yang dipusatkan di sentra kerajinan logam desa Tumang ini, mendapat apresiasi yang baik di masyarakat kususnya pada dua perusahaan yang menjadi mitra pengabdian, dimana setelah dilakukan pendidikan pelatihan, pendampingan, perancangan desain dan supervisi terjadi beberapa beberapa perubahan dan peningkatan diantaranya dari aspek kecepatan prosuksi khususnya setelah muncul penerapan teknologi tapat guna (TTG) pada teknik spinning. Awalnya pengrajin hanya mengenal teknik pembentukan manual dengan cara ondel dan kenteng yang dalam pengerjaanya sangat lamban. Sebagai gambaran untuk pembuatan milk can dengan cara kenteng manual dalam satu hari hanya menghasilkan satu karya. Namun setelah digunakan alat TTG dalam satu hari dapat menghasilkan 20 buah karya. Selain itu, terjadi juga peningkatan dan perubahan dibeberapa aspek. Antara lain terjadi kenaiakan omset penjualan, terjadi peningkatan efektifitas cara kerja, munculnya sistem pemasaran dan muncul produk baru dari hasil pengembangan desain.

\section{DAFTAR PUSTAKA}

Ambar Teguh Sulistiyani, 2004, Kemitraan Dan Model Model Pemberdayaan, yogyakarta : Gava Media

Soegeng Toekio, at all, 1987, Pengantar Apresiasi Seni Rupa, ASKI Surakarta

Soedarsono RM, 2001, Metodologi Penelitian Seni Pertunjukan dan Seni Rupa, Bandung : MSPI
Kotler, Philip. (2002). Manajemen Pemasaran, Edisi Milenium, Jakarta: PT. Prenhallindo.

https://id.wikipedia.org/wiki/Powder_coating

Narasumber wawancara:

Sudarto, perajin logam, usia 53 tahun

Alamat: Desa Tumang, Kecamatan Cepogo, Kabupaten Boyolali 